\title{
Quality test of long-jawed mackerel (Rastrelliger sp.) fish flour
}

\author{
Domili, I., *Labatjo, R., Ntau, L.A., Anasiru, M.A. and Arbie, F.Y. \\ Department of Nutrition, Gorontalo Health Polytechnic, Gorontalo, Indonesia
}

\begin{abstract}
Article history:
Received: 18 December 2019

Received in revised form: 21

January 2020

Accepted: 23 January 2020

Available Online: 26

February 2020
\end{abstract}

\section{Keywords:}

Long-jawed mackerel,

Fish flour,

Protein,

Fat,

Calcium

\section{DOI:}

https://doi.org/10.26656/fr.2017.4(3).418

\begin{abstract}
This research was aimed to evaluate the quality of long-jawed mackerel fish flour, resulted from four different treatments, based on specific criteria, namely water content, protein, fat and calcium. This was a True Experimental Design Post test-Only Control Design research with a completely randomized design (CRD). The experimental method consisted of four treatments. Data regarding protein content was obtained by using Kjehdal method, water content using oven method, fat content using Soxhlet while calcium content using the Atomic Absorption Spectrophotometry method. The research data were processed statistically for ANOVA (Analysis of Variance) and continued with the LSD (Least Significance Different) test. ANOVA test analysis results showed that the water content ( $p$ $=0.02)$, protein $(\mathrm{p}=0.00)$, fat $(\mathrm{p}=0.00)$, and calcium $(\mathrm{p}=0.00)$ significantly different between the four treatments. The fish flour produced meets quality standard based on Indonesian standard of fish flour registered by number Indonesian National Standard (SNI) 2715: 2013 in terms of water content, protein and fat.
\end{abstract}

\section{Introduction}

Fisheries resources are a commodity of Gorontalo Province. Geographically, the potential of fisheries in Gorontalo Province is quite promising. Data from the Gorontalo Province Central Statistics Agency in 2017 recorded that 134,707 tons of fish production came from marine fisheries. This production increased by $13.8 \%$ of production in 2016 (Gorontalo Province Central Statistics Agency, 2017). Thus, this abundant fishery product needs to be endeavoured to be processed so that it can increase its nutritional value and economic value. In general, fish is high in protein and low in calorie. It is an important source of omega - 3 fatty acids and minerals, such as calcium and phosphorus (Neiva et al., 2011). Therefore, consuming fish can benefit health.

Consuming omega - 3 in sufficient amounts can reduce cholesterol content in the blood, reduce the risk of heart disease, the risk of atherosclerosis and can kill cancer cells and cure rheumatoid arthritis symptoms (Sukarsa, 2004). Long-jawed mackerel contains many nutritional values (Irmawan, 2009). For example, fresh long-jawed mackerel has $0.45 \mathrm{~g}$ omega-3 per 100 grams and $2.17 \mathrm{~g}$ in flour (Nalendrya et al., 2016). The chemical composition of long-jawed mackerel consists of water $75.97 \%$, ash $1.02 \%$, fat $10.13 \%$, crude protein $10.23 \%$, carbohydrate $2.65 \%$, and pH 5.68 (Santoso et al., 2011).
Fish can be classified as perishable foods. Perishable foods are susceptible to decay and require proper handling such as further processing to increase their shelf life by inhibiting and eliminating the activity of microorganisms (Irawan, 2005). An example of such an appropriate process is by making fish flour.

This research is basically making long-jawed mackerel fish flour using various technique. This research is aimed to evaluate the quality of long-jawed mackerel fish flour, resulted from four different treatments, based on specific criteria, namely water content, protein, fat and calcium.

\section{Materials and methods}

\subsection{Research design}

True Experimental Design Posttest-Only Control Design research with a completely randomized design was used. The experimental method consisted of four treatments. The treatment is carried out as follows:

$\mathrm{F} 0=$ steaming for 10 mins with heating $80^{\circ} \mathrm{C}$ for 5 hrs (control)

$\mathrm{F} 1=$ steaming for 10 mins by pressing water and oil and heating $80^{\circ} \mathrm{C}$ for $5 \mathrm{hrs}$

$\mathrm{F} 2=$ steaming for 10 mins with heating $90^{\circ} \mathrm{C}$ for 5 hrs 
$\mathrm{F} 3$ = steaming for 10 mins by pressing water and oil and heating $90^{\circ} \mathrm{C}$ for $5 \mathrm{hrs}$

\subsection{Materials}

Fresh long-jawed mackerel was used as the main ingredient of fish flour. To reduce the fish odour, lime juice was used in the process of flour making. Chemicals such as hexane, antioxidant Butylated hydroxytoluene, distilled water, $\mathrm{Na}_{2} \mathrm{CO}_{3}, \mathrm{NaOH}, \mathrm{CuSO}_{4} 5 \mathrm{H}_{2} \mathrm{O}$, sodium tartrate, bovinalbumin Folin-Ciocalteu phenolreagenz, were used to measure protein and fat content.

\subsection{Chemical analysis}

Analysis of protein content was done by using Kjehdal method while fat was measured by using Soxhlet (AOAC, 2005). Water content was determined by using the oven method (AOAC, 1995). Meanwhile, Atomic Absorption Spectrophotometry method was used to calculate calcium level.

\subsection{Data analysis}

The results obtained by the analyses were statistically evaluated by one-way analysis of variance (ANOVA) in order to observe the effect of different formulations on quality parameters of long-jawed fish flour. For significantly different treatments, LSD (Least Significance Different) test was used $(p<0.05)$.

Moreover, protein, fat and water content of every fish flour produced from four treatments were analysed by comparing test results with standard quality fish flour based on National Indonesian Standard 2715: 2013.

\subsection{Producing of fish flour}

Firstly, the fresh long-jawed mackerel was dressed and washed with running water. Then, fish was steamed for 10 mins. Steamed fish then, was deboned and marinated with lime juice for 30 mins. Lime juice ratio was 3 tbsps. per kg of fish.

Next step was pressing the fish by using a manual pressing machine to remove the water and oil contained. Some fish meat was not pressed. Then, both fish types of meat were dried at $80^{\circ} \mathrm{C}$ and $90^{\circ} \mathrm{C}$ for $5 \mathrm{hrs}$. After the drying process, dried fish meat was refined by using a blender. Finally, it was shifted using 80 mesh sieves (Figure 1).

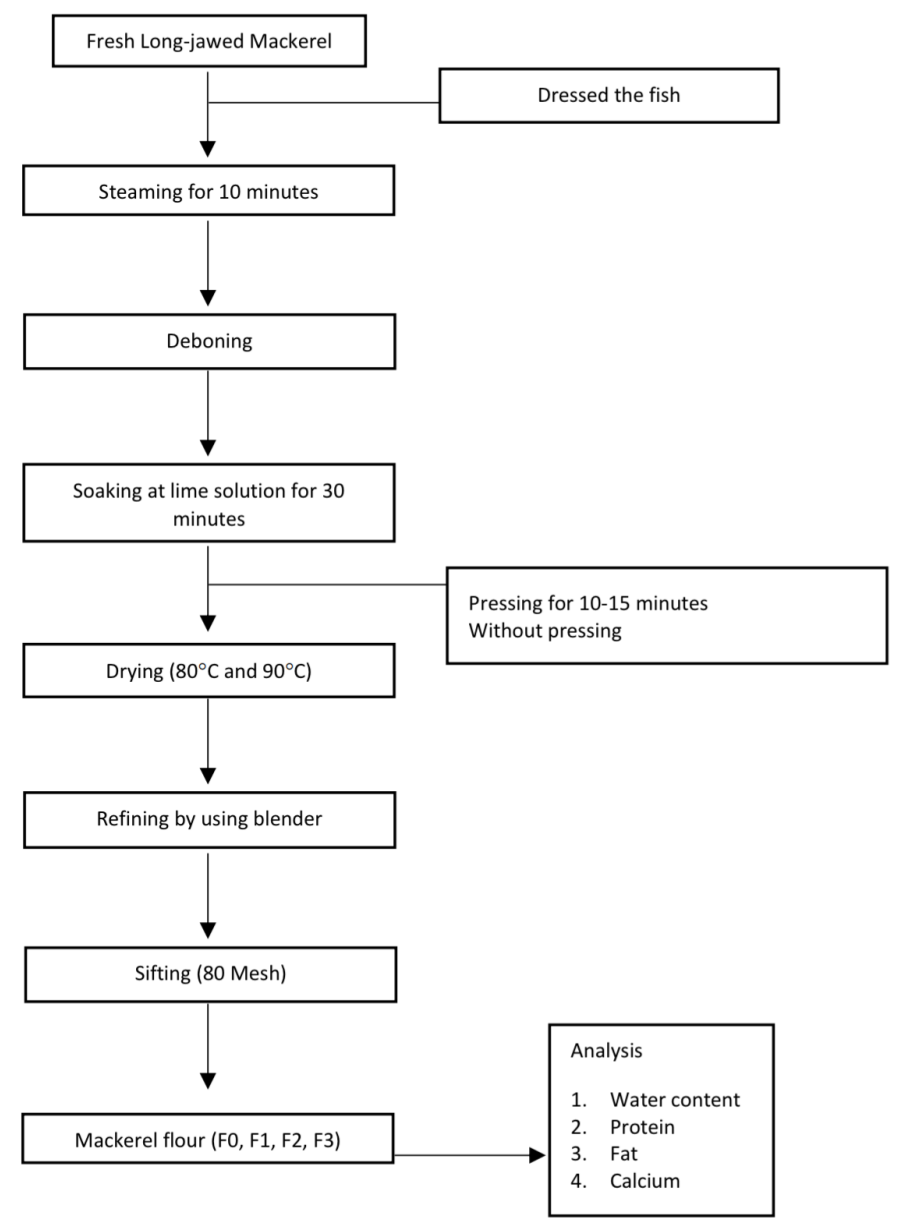

Figure 1. Research flow chart

\section{Results and discussion}

The results of the analysis of water content, protein, fat and calcium of mackerel flour produced in this study, are presented in Table 1. ANOVA test analysis results showed that the water content, protein, fat and calcium differed significantly between the four treatments. Thus, it can be said the treatments of steaming and heating with different temperatures and steaming by pressing water and oil with different temperature heating gave different

Table 1. Results of mackerel fish flour analysis

\begin{tabular}{|c|c|c|c|c|c|c|}
\hline \multirow{2}{*}{ Test results } & \multicolumn{4}{|c|}{ Treatment } & \multirow{2}{*}{ ANOVA 5\% } & \multirow{2}{*}{$\operatorname{LSD} 5 \%$} \\
\hline & F0 & $\mathrm{F} 1$ & $\mathrm{~F} 2$ & F3 & & \\
\hline Water content $(\%)$ & $8.32^{\mathrm{a}}$ & $4.09^{b}$ & $8.61^{a}$ & $3.81^{\mathrm{b}}$ & $0.02 *$ & 2.83 \\
\hline Protein (\%) & $78.75^{\mathrm{c}}$ & $82.19^{\mathrm{abd}}$ & $80.92^{\mathrm{ac}}$ & $83.37^{\text {bd }}$ & $0.00 *$ & 1.99 \\
\hline Fat $(\%)$ & $6.92^{\mathrm{a}}$ & $6.15^{\mathrm{abc}}$ & $4.90^{\mathrm{b}}$ & $5.05^{\mathrm{bc}}$ & $0.00 *$ & 1.26 \\
\hline Calcium (ppm) & $63.59^{\mathrm{a}}$ & $72.70^{\mathrm{b}}$ & $68.19^{\mathrm{ab}}$ & $83.43^{\mathrm{c}}$ & $0.00^{*}$ & 7.72 \\
\hline
\end{tabular}

*significantly different in the ANOVA test with a level of 0.05 . Different superscript indicates significant difference in the LSD test at 0.05 . 
results and can distinguish the water content, protein, fat and calcium of long-jawed mackerel fish flour.

Based on LSD further tests, for the analysis of water content, treatment with steaming and heating $80^{\circ} \mathrm{C}$ and $90^{\circ} \mathrm{C}$ did not differ significantly. Similarly, the steaming treatment with water and oil pressing and heating $80^{\circ} \mathrm{C}$ and $90^{\circ} \mathrm{C}$, the water content in the flour produced did not differ significantly. The thing that is different is just the water content at the level of just steaming treatment compared with steaming accompanied by pressing water and oil. Therefore, it can be concluded that the factors that influence the water content of the fish flour produced are the treatment of pressing water and oil from fish meat after experiencing steaming for 10 mins.

Further analysis of the difference with the LSD test on protein content showed that there was no significant difference between the protein content of mackerel flour produced from the steaming treatment followed by heating with temperatures of $80^{\circ} \mathrm{C}$ and $90^{\circ} \mathrm{C}$. While the protein content of fish flour produced from the steaming treatment by pressing water and oil and heating $80^{\circ} \mathrm{C}$ and $90^{\circ} \mathrm{C}$, the same value produced from the steaming treatment accompanied by heating at a temperature of $90^{\circ} \mathrm{C}$.

However, steaming treatment accompanied by heating $80^{\circ} \mathrm{C}$ produces mackerel fish flour with different protein levels with steaming treatment with water and oil pressing and heating $80^{\circ} \mathrm{C}$ and $90^{\circ} \mathrm{C}$. Similarly, mackerel fish flour resulting from steaming treatment accompanied by heating $90^{\circ} \mathrm{C}$ has different protein levels with the treatment of steaming and pressing water and oil followed by heating at a temperature of $90^{\circ} \mathrm{C}$.

The results of the LSD test analysis for the fat content of mackerel flour produced from the steaming treatment accompanied by heating $80^{\circ} \mathrm{C}$ are the same value as the steaming treatment with water and oil pressing and heating $80^{\circ} \mathrm{C}$. Uniquely, in addition, steaming treatment by heating $80^{\circ} \mathrm{C}$ produces flour mackerel with fat content that does not differ between the two other treatments. The levels of fishmeal fat produced in the steaming treatment accompanied by heating $90^{\circ} \mathrm{C}$, did not differ from the treatment of steaming with water and oil pressing accompanied by heating $80^{\circ}$ and $90^{\circ} \mathrm{C}$. Thus, the LSD test for the fat content of mackerel fish flour produced from the treatment steaming and heating $80^{\circ} \mathrm{C}$ results are different from the treatment of steaming by heating $90^{\circ} \mathrm{C}$ and steaming accompanied by pressing water and oil accompanied by heating $90^{\circ} \mathrm{C}$.

Further analysis of LSD, showed no significant difference in the levels of calcium $(\mathrm{Ca})$ of mackerel flour in steaming and heating treatment $80^{\circ} \mathrm{C}$ and $90^{\circ} \mathrm{C}$. Similarly, the levels of $\mathrm{Ca}$ of fish flour with steaming treatment accompanied by pressing water and oil followed by heating $80^{\circ} \mathrm{C}$, are not significantly different from steaming and heating $90^{\circ} \mathrm{C}$. However, steaming treatment by heating $80^{\circ} \mathrm{C}$ produces fish flour with different levels of $\mathrm{Ca}$ with steaming treatment accompanied by pressing water and oil and heating at a temperature of $80^{\circ} \mathrm{C}$ and $90^{\circ} \mathrm{C}$. The steaming treatment by pressing water and oil and heating $90^{\circ} \mathrm{C}$ produces mackerel fish flour with levels of $\mathrm{Ca}$ that are significantly different from the other three treatments.

\subsection{Water content}

Average water content ranges between $3.81 \%$ and $8.61 \%$. The formula that contains the highest water content is F2 and the lowest is F3. The highest water content is found in fish flour by the steaming method. Whereas the steaming and pressing method of water and oil produces low water content.

Separation of fat can affect water content. The reaction of glycerol esterification with fatty acids produces tripalmitin and water fat molecules (Winarno, 2002). Therefore, in the process of pressing water and oil, the water content in fish flour will decrease. In addition to the water contained in mackerel meat, water that is bound in oil or fat molecules is also reduced. The end result is mackerel flour which has low water content.

According to the standard of fish flour quality based on SNI 2715: 2013, samples of fish flour by the steaming method without water and oil pressing that meet the quality standard A for water content, which is around 6$10 \%$. Fish flour with steaming treatment by pressing water and oil has a moisture content below $6 \%$. This can cause the mackerel flour to be hygroscopic (Fatmawati and Mardiana, 2014). This condition will cause the mackerel flour produced will tend to absorb water coming from the surrounding environment. Thus, mackerel flour cannot be stored or placed in a humid place because it will cause a faster damage process. High water content (more than 10\%) will cause fish flour to break down faster. Damage to the flour with high water content is caused by mold growth (Winarno, 2002).

Mold will produce mycotoxins that are harmful to health (Saputra, 2015). Mycotoxins that are commonly found in foods such as aflatoxin, ochratoxin, zearalenone and fumonisin. Aflatoxins are carcinogenic, hepatotoxic, immunosuppressant and mutagenic. Octathoxin can cause kidney poisoning and is carcinogenic (Saputra, 2015). Zearalenone can be estrogenic. Excessive oestrogen levels cause weight gain, low sex drive, fluid buildup in the body, breast cancer, endometriosis and 
thyroid problems (Swari, 2017). While fumonisin can cause cancer (Saputra, 2015).

\subsection{Protein}

The protein content of mackerel flour produced ranged between $78.75 \%$ and $83.37 \%$. All of the mackerel flour samples tested to meet the quality standard of fish flour based on SNI 2715: 2013 quality A, which is at least $60 \%$. Thus, the mackerel flour produced can be said to be of good quality protein.

The highest protein content is found in mackerel flour with steaming treatment by pressing water and oil. The steaming method can reduce the risk of protein damage due to coagulation (Fatmawati and Mardiana, 2014). The results of research conducted by Fatmawati and Mardiana (2014), showed that in the manufacture of cork fish flour, the boiling method can reduce the quality of protein due to dissolved and coagulated protein in hot water. While the steaming method is proven effective in preventing a decrease in protein levels (Fatmawati and Mardiana, 2014).

Fish meat is a source of protein that has many benefits. Fish protein helps the growth and development of brain cells and plays a role in cell regeneration, enzymes and hormones (Susanto and Fahmi, 2012). In addition, protein supports the immune system, as a source of energy other than carbohydrates and fats, means of transporting oxygen, supporting the coordination of motion, as a muscle binder, an enzymebased material, and as a mediator of nerve impulses (Primasoni, 2010). Other benefits of fish protein are easy to digest even for the digestion of infants over 6 months compared to beef protein (Andriani and Bambang, 2012; Simanjuntak, 2016).

Thus, the whole sample of fish flour produced in this study can be an alternative source of protein. Mackerel fish flour products can be used as a basic ingredient or in addition to the manufacture of processed foods that aim to increase the protein content of a food product. The expected end result is an increase in protein intake individually or in groups of people.

\subsection{Fat}

The value of mackerel flour fat content produced in this study ranged from $4.90 \%$ and $6.92 \%$. Based on INS 2715: 2013 fish flour standards, fat content of mackerel flour produced by the four levels of treatment meets the quality standard of fish flour A, which is a maximum of $10 \%$ (National Standardization Agency, 2013). Thus, the treatment of steaming, pressing water and oil as well as heating at a temperature of $80^{\circ} \mathrm{C}$ and $90^{\circ} \mathrm{C}$ is said to be beneficial in terms of maintaining fat levels according to standards.

High levels of fat will speed up the process of rancidity or damage to fish flour. Fat content exceeding $12 \%$ will cause the process of damage faster so that shorten the shelf life and affect the physical appearance of fishmeal that looks oily (Khalishi, 2011; Handoyo and Assadad, 2016). Mackerel flour produced at all treatment levels in this study had a fat content below $12 \%$. So that the mackerel flour can be stored longer.

Fat is hydrophobic (Winarno, 2002). Fat compounds are not soluble in water so steaming treatment does not affect the quality of fat. However, water and oil presses treatment results in mackerel fish flour with different fat content. This treatment will certainly reduce the fat content of mackerel flour.

In addition to the steaming and pressing treatment of water and oil, the temperature factor also plays a role in the fat content of mackerel flour produced. The heating treatment will cause the removal of fat molecules. This is due to the movement of molecules due to heating (Winarno, 2002). The temperature and time of heating are inversely proportional to the fat content of fish flour (Sipayung et al., 2007). The higher the temperature and the longer the heating time will reduce the fat content of fish flour.

Fat is a macronutrient has various benefits. Fat functions as an energy source with higher calories than carbohydrates and protein. Fat also plays a role in the process of metabolism of fat-soluble vitamins, namely vitamins $\mathrm{A}, \mathrm{D}, \mathrm{E}$ and $\mathrm{K}$. The process of body temperature regulation requires fat. Essential fatty acids function in maintaining healthy skin including preventing inflammation (Winarno, 2002).

Mackerel as a basic ingredient in making fish flour in this study has a fat content of $10.13 \%$ (Santoso et al., 2011). Mackerel is rich in omega-3 (2.6 g) compared to salmon (1.4 g). Omega-3 is useful for brain intelligence and heart and blood vessel health (Fish Quarantine Agency, 2018).

\subsection{Calcium}

Test results using the SSA method, calcium (Ca) concentration of mackerel flour produced in this study ranged between $63.59 \mathrm{ppm}$ and $83.43 \mathrm{ppm}$. Treatment of steaming with water and oil pressing and heating to a temperature of $90^{\circ} \mathrm{C}$, resulting in the highest levels of calcium. Conversely, steaming treatment accompanied by heating with a temperature of $80^{\circ} \mathrm{C}$ produces the lowest levels of calcium.

The heating process can affect calcium 
levels. Minerals, including calcium, will experience precipitation when heated (Saputra et al., 2016). Mackerel fish flour heated to a temperature of $90^{\circ}$ $\mathrm{C}$ has a higher calcium content compared to a temperature of $80^{\circ} \mathrm{C}$. So, the heating temperature factor can increase the calcium content of fish flour products in this study.

Calcium is a macromineral that is needed by the body. Calcium plays a role in the growth of bones and teeth (Aryati and Dharmayanti, 2014; Afianti and Indrawati, 2015; Rautiainen et al., 2016). Bone density is also influenced by calcium intake, although not significantly (Tai et al., 2015). Adequate fish consumption is proven to have no negative effect on bone density (Perna et al., 2017).

The benefits of calcium are not limited to the growth of bones and teeth. The results showed that the calming effect on fish calcium can help reduce blood pressure during stress (Aryati and Dharmayanti, 2014). In addition, low fish consumption is associated with an increased risk of hip fracture in elderly men (RosendahlRiise et al., 2018). In childhood and adolescence, calcium increases height growth (Weaver, 2015; Fang et al., 2017). Adequate calcium intake can also reduce the risk of colorectal cancer (Yang et al., 2018).

\section{Conclusion}

The fish flour produced meets quality standard based on Indonesian standard of fish flour registered by number Indonesian National Standard (SNI) 2715: 2013 in terms of water content, protein and fat. Moreover, long-jawed mackerel flour produced can be used as a basic ingredient or substitute for processed food products that are high in protein and low in fat. Although this research results showed that long-jawed mackerel fish flour is high in nutritional value, further research is needed to assess the shelf life of mackerel fish flour products.

\section{Conflict of Interest}

The authors certify declared no conflict of interest.

\section{Acknowledgments}

The authors would like to acknowledge the technical and funding support provided by Gorontalo Health Polytechnic.

\section{References}

Afianti, F. and Indrawati, V. (2015). The Effect of Addition of Cork (Ophiocephalus striatus) and Water Flour to Organoleptic Properties of Crackers.
Journal of Catering. University of Surabaya, 4(1), 46-55.

Andriani, M. and Bambang, W. (2012). Introduction to Community Nutrition. Jakarta: Kencana Prenada Media Group.

AOAC (1995). Official Methods of Analysis. Washington DC: AOAC

AOAC (2005). Official Methods of Analysis. Washington DC: AOAC

Aryati, E. and Dharmayanti, A.W.S. (2014). Benefits of Fresh Anchovy (Stolephorus sp) on Bone and Tooth Growth. ODONTO: Dental Journal. Sultan Agung Islamic University, 1(2), 52-56. https:// doi.org/10.30659/odj.1.2.52-56

Fish Quarantine Agency, P.M. and KHP. (2018). Rich in Omega 3, Alternative Puffed Salmon Substitute Salmon. Retrieved on September 18, 2019 from website: https://kkp.go.id/bkipm/artikel/8083-kayaakan-omega-3-ikan-kembung-alternatif-per replacement-salmon

Gorontalo Province Central Statistics Agency (2017). Capture Fisheries Production by Regency/City in Gorontalo Province 2017. Gorontalo, Indonesia: Gorontalo Province Central Statistics Agency.

National Standardization Agency. (2013). SNI 2715: 2013: Fish Flour - Feed Raw Materials. Indonesia: SNI

Fang, A., Li, K., Li, H., Guo, M., He, J., Shen, X. and Song, J. (2017). Low Habitual Dietary Calcium and Linear Growth from Adolescence to Young Adulthood: Results from the China Health and Nutrition Survey. Scientific Reports, 7(1), 1-11. https://doi.org/10.1038/s41598-017-08943-6.

Fatmawati and Mardiana. (2014). Cork Fish Flour as a Source of Protein (Food Supplement). Journal of Bionature, 15(1), 54-60.

Handoyo, W. and Assadad, L. (2016). Characterization of the Production Process and Quality of Fish Flour in Several Small Scale Processors presented at the XIII Annual National Seminar on Fisheries and Marine Research Results., p. 197-205. Yogyakarta: Gajah Mada University.

Irawan, A. (2005). Preservation of Fishery Products. Solo: CV. Various.

Irmawan, S. (2009). Status of mackerel fisheries in Barru district. Brawijaya University. Malang.

Khalishi, Z. (2011). Characterization and Formulation of Rengginang Tembang Fish Flour (Sardinella fimbriata). Indonesia: Bogor Agricultural University, MSc. Thesis.

Nalendrya, I., Ilmi, I. and Arini, F. (2016). Long-Jawed 
Mackerel Fish Sausage (Rastrelliger kanagurta L.) As Food Source of Omega 3. Journal of Application of Food Technology, 5(3), 71-75. https:// doi.org/10.17728/jatp.178

Neiva, C.R.P., Machado, T.M., Tomita, R.Y., Furlan, É.F., Lemos Neto, M.J. and Bastos, D.H.M. (2011). Fish crackers development from minced fish and starch: an innovative approach to a traditional product. Food Science and Technology, 31(4), 973979. https://doi.org/10.1590/S010120612011000400024

Perna, S., Avanzato, I., Nichetti, M., D’Antona, G., Negro, M. and Rondanelli, M. (2017). Association between Dietary Patterns of Meat and Fish Consumption with Bone Mineral Density or Fracture Risk: A systematic Literature. Nutrients, 9(9), 1029. https://doi.org/10.1590/S0101-20612011000400024

Primasoni, N. (2010). Benefits of Protein to Support Sports Activities, Growth, and Early Childhood Development. Retrieved on September 13, 2019 from website: http://staff.uny.ac.id/sites/default/files/ perearch/nawan-primasoni-spd-kor-m-or/benefitsprotein-for-perkembangan.pdf.

Rautiainen, S., Manson, J.E., Lichtenstein, A.H. and Sesso, H.D. (2016). Dietary supplements and disease prevention-a global overview. Nature Reviews Endocrinology, 12(7), 407-420. https:// doi.org/10.1038/nrendo.2016.54.

Rosendahl-Riise, H., Sulo, G., Karlsson, T., Drevon, C.A., Dierkes, J. and Tell, G.S. (2018). The Limited Benefit of Fish Consumption on Risk of Hip Fracture among Men in the Community-based Hordaland Health Study. Nutrients, 10(7), 873. https://doi.org/10.3390/nu10070873.

Santoso, J., Ling, F. and Handayani, R. (2011). Effect of Composition and Cold Storage on Changes in Characteristics of Stingray Surimi (Trygon sp.) And Mackerel (Rastrelliger sp.), Aquatic Journal, 2(2). 115.

Saputra, D. (2015). Mycotoxins and their Danger of Contamination in Foodstuffs. Retrieved on September 6, 2019 from Binus University Faculty of Engineering website: https:// foodtech.binus.ac.id/2015/06/24/mikotoksin-danbahaya-kontaminasinya-pada-bahan-pangan/

Saputra, R., Widiastuti, I. and Nopianti, R. (2016). Physicochemical Characteristics and Sensory of Dumpling Crackers with a Combination of Motan Fish Flour (Thynnichthys thynnoides). Journal of Fisheries Product Technology, 5(2), 167-177.

Sipayung, M.Y., Suparmi and Dahlia (2007). The Effect of Steaming Temperature on the Physical Properties of Flaky Fish Flour. Ecology, 3, 66-68.

Sukarsa, D. (2004). Study of the activity of omega 3 fatty acids of marine fish in mice as an experimental animal model. Agricultural Technology Bulletin, 7 (1), 68-79.

Susanto, E. and Fahmi, A.S. (2012). Functional Compounds of Fish: Its Application in Food. Journal of Application of Food Technology, 1(4), 95-102.

Swari, R.C. (2017). 6 Health Disorders Due to Excess of Estrogen Hormone. Retrieved on September 6, 2019 from website: Available at: https://hellosehat.com/ life-sehat/tips-sehat/effect-health-hormoneestrogens/.

Tai, V., Leung, W., Grey, A., Reid, I.R. and Bolland, M.J. (2015). Calcium intake and bone mineral density: systematic review and meta-analysis. $B M J$ (Online), 351, 1-14. https://doi.org/10.1136/ bmj.h4183.

Weaver, C.M. (2015). Parallels between nutrition and physical activity: Research questions in the development of peak bone mass. Research Quarterly for Exercise and Sport, 86(2), 103-106.

Winarno, F. (2002). Food and Nutrition Chemistry. Jakarta: Gramedia.

Yang, W., Liu, L., Masugi, Y., Qian, Z.R., Nishihara, R., Keum, N., Wu, K., Smith-Warner, S., Ma, Y., Nowak, J.A., Momen-Heravi, F., Zhang, L., Bowden, M., Morikawa, T., Silva, A.D., Wang, M., Chan, A.T., Fuchs, C.S., Meyerhardt, J.A., Ng, K., Giovannucci, E., Ogino, S. and Zhang, X. (2018). Calcium intake and risk of colorectal cancer according to expression status of calcium-sensing receptor (CASR). Gut, 67(8), 1475-1483. https:// doi.org/10.1136/gutjnl-2017-314163. 